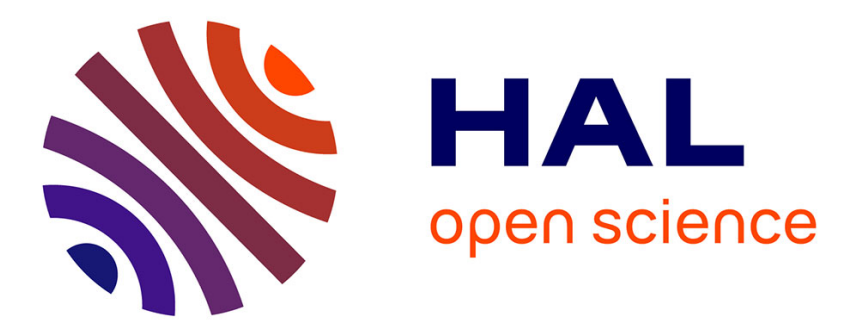

\title{
[CpMoCl(PMe3)3][BF4] and [Cp*MoCl(PMe3)3][PF6]
}

James C Fettinger, Heinz-Bernhard Kraatz, Rinaldo Poli, Arnold L. Rheingold

\section{To cite this version:}

James C Fettinger, Heinz-Bernhard Kraatz, Rinaldo Poli, Arnold L. Rheingold. [Cp$\mathrm{MoCl}(\mathrm{PMe} 3) 3][\mathrm{BF} 4]$ and $[\mathrm{Cp} * \mathrm{MoCl}(\mathrm{PMe} 3) 3][\mathrm{PF} 6]$. Acta Crystallographica Section C: Crystal Structure Communications [1968-2013], 1995, 51 (3), pp.364-367. 10.1107/S010827019400898X . hal03531376

\section{HAL Id: hal-03531376 https://hal.science/hal-03531376}

Submitted on 18 Jan 2022

HAL is a multi-disciplinary open access archive for the deposit and dissemination of scientific research documents, whether they are published or not. The documents may come from teaching and research institutions in France or abroad, or from public or private research centers.
L'archive ouverte pluridisciplinaire HAL, est destinée au dépôt et à la diffusion de documents scientifiques de niveau recherche, publiés ou non, émanant des établissements d'enseignement et de recherche français ou étrangers, des laboratoires publics ou privés. 


\title{
$\left[\mathrm{CpMoCl}\left(\mathrm{PMe}_{3}\right)_{3}\right]\left[\mathrm{BF}_{4}\right]$ and $\left[\mathrm{Cp} * \mathrm{MoCl}\left(\mathrm{PMe}_{3}\right)_{3}\right]\left[\mathrm{PF}_{6}\right]$
}

\author{
James C. Fettinger, Heinz-Bernhard KraAtz and \\ RINALDO POLI* \\ Department of Chemistry and Biochemistry, \\ University of Maryland, College Park, \\ Maryland 20742, USA \\ ARNOLD L. RHEINGOLD \\ Department of Chemistry, University of Delaware, \\ Newark, DE 19719, USA
}

(Received 18 January 1994; accepted 2 August 1994)

\begin{abstract}
Chloro $\left(\eta^{5}\right.$-cyclopentadienyl)tris (trimethylphosphine)molybdenum(III) tetrafluoroborate, $\left[\mathrm{MoCl}\left(\mathrm{C}_{5} \mathrm{H}_{5}\right)\right.$ $\left.\left(\mathrm{C}_{3} \mathrm{H}_{9} \mathrm{P}\right)_{3}\right]\left[\mathrm{BF}_{4}\right]$, was obtained from the oxidation of $\left[\mathrm{MoH}\left(\mathrm{C}_{5} \mathrm{H}_{5}\right)\left(\mathrm{PMe}_{3}\right)_{3}\right]$ by $\mathrm{AgBF}_{4}$, followed by crystallization from dichloromethane. Chloro $\left(\eta^{5}\right.$-pentamethylcyclopentadienyl)tris(trimethylphosphine)molybdenum(III) hexafluorophosphate, $\left[\mathrm{MoCl}\left(\mathrm{C}_{10} \mathrm{H}_{15}\right)\left(\mathrm{C}_{3} \mathrm{H}_{9} \mathrm{P}\right)_{3}\right]-$ $\left[\mathrm{PF}_{6}\right]$, was obtained from the reaction of $\left[\mathrm{MoCl}_{2}\right.$ $\left(\mathrm{C}_{10} \mathrm{H}_{15}\right)\left(\mathrm{C}_{3} \mathrm{H}_{9} \mathrm{P}\right)_{2}$ ] with $\mathrm{TIPF}_{6}$ and $\mathrm{PMe}_{3}$ in dichloromethane. Both cations adopt a four-legged piano-stool arrangement.
\end{abstract}




\section{Comment}

Odd-electron complexes having the general formula $\left[\left(\text { ring) } M X_{2-n} L_{2+n}\right]^{n+}\right.$ (ring = cyclopentadienide or substituted analogue; $X=\mathrm{Cl}, \mathrm{Br}, \mathrm{I} ; L=\mathrm{P} R_{3} ; n=0$ or 1 ) and possessing a four-legged piano-stool configuration are now well established (Poli, 1992). As part of our ongoing investigation of $\mathrm{CpMo}^{\mathrm{III}}$ complexes, we now report the crystal structures of $\left[\mathrm{CpMoCl}\left(\mathrm{PMe}_{3}\right)_{3}\right]\left[\mathrm{BF}_{4}\right](1)$ and $\left[\mathrm{Cp} * \mathrm{MoCl}\left(\mathrm{PMe}_{3}\right)_{3}\right]\left[\mathrm{PF}_{6}\right](2)$, where $\mathrm{Cp}$ and $\mathrm{Cp} *$ are $\eta^{5}$ cyclopentadienyl and $\eta^{5}$-pentamethylcyclopentadienyl ligands, respectively.
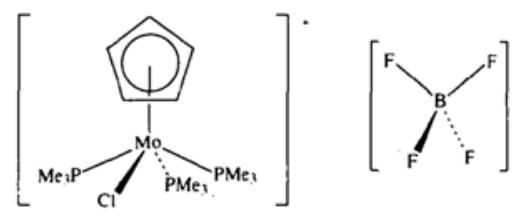

(1)

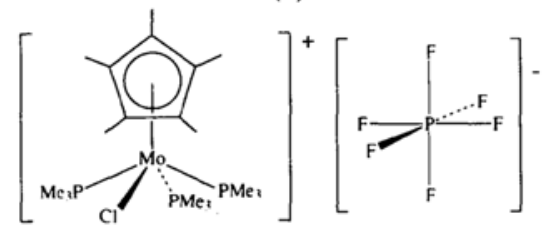

(2)

A different salt of the $\left[\mathrm{CpMoCl}\left(\mathrm{PMe}_{3}\right)_{3}\right]^{+}$cation [with the $\mathrm{PF}_{6}^{-}$anion, compound (3)] was prepared previously by one-electron oxidation of $\left[\mathrm{CpMoCl}\left(\mathrm{PMe}_{3}\right)_{3}\right]$ and characterized crystallographically (Abugideiri, Kelland, Poli \& Rheingold, 1992). However, while compound (3) crystallizes in the orthorhombic space group $P 22_{1} 2_{1}$, compounds (1) and (2) crystallize under the same conditions in the monoclinic space group $P 2_{1} / c$.

A comparison of selected bond distances and angles for the cations of compounds (1) and (2) is given in Table 3. In both structures, the ions are well separated from each other. The average $\mathrm{B}-\mathrm{F}$ bond length in (1) is 1.317 (13) $\AA$. The F-B-F angles are very close to the expected tetrahedral value, being in the range 106$114^{\circ}$ with an average value of $109.1(10)^{\circ}$. The $\mathrm{PF}_{6}$ anion in compound (2) is either highly thermally active or disordered among different orientations too close to each other to be distinguished in the $E$ map. Therefore, it was restrained to adopt $O_{h}$ symmetry with $\mathrm{P}-\mathrm{F}$ bond lengths of 1.52 (1) $\AA$.

Views of the cations of (1) and (2) are shown in Figs. 1 and 2, respectively. Both ions exhibit a typical fourlegged piano-stool geometry. The metric parameters and angular distortions of the cation in compound (1) are significantly different from those of the same cation in the previously reported structure of (3). In particular, the cation in (3) has a shorter $\mathrm{Mo}-\mathrm{Cl}$ distance [2.427 (9) versus 2.509 (3) $\AA$ in (1)] and longer Mo- $\mathrm{P}$ distances [2.504 (7) $\AA$ for the $\mathrm{PMe}_{3}$ ligand trans to $\mathrm{Cl}$ and an average of 2.545 (12) $\AA$ for the other two $\mathrm{PMe}_{3}$ ligands, versus 2.455 (2) and 2.505 (2) $\AA$, respectively, for (1)]. The Mo-Cnt distance in (1), where Cnt is the centroid of the cyclopentadienyl moiety, however, is statistically equivalent to that in compound (3) [1.986(18) $\AA$. The $\mathrm{Cnt}-\mathrm{Mo}-\mathrm{L}$ angles are more homogeneous in (1) (within the range $107-112^{\circ}$ ) than in (3) flarger for the $\mathrm{Cl}$ ligand $\left[123.9(8)^{\circ}\right]$ and the $\mathrm{PMe}_{3}$ ligand trans to $\mathrm{Cl}\left[113.3(8)^{\circ}\right]$, and smaller for the other two $\mathrm{PMe}_{3}$ ligands [104.5(8) and $\left.\left.104.0(8)^{\circ}\right]\right\}$. The angular changes of the four monodentate ligands on going from compound (1) to compound (3) can be viewed collectively as being analogous to a Berry pseudorotation for the interconversion of trigonal-bipyramidal and square-pyramidal structures (Huheey, 1983) (see scheme below). The fact that the nature of the anion (and therefore consequent minor differences in packing forces) causes such significant changes in the angular distorsions for the $\left[\mathrm{CpMoCl}\left(\mathrm{PMe}_{3}\right)_{3}\right]^{+}$cation, suggests that the pseudo-rotation illustrated below has a smooth potential-energy surface for this ion. The phenomenon of the correlation between the $\mathrm{Cnt}-\mathrm{Mo}-L$ angles for two ligands in relative trans positions in a four-legged piano-stool geometry has been termed 'angular trans influence' (Poli, 1990) and has been the subject of a recent theoretical analysis (Lin \& Hall, 1993).

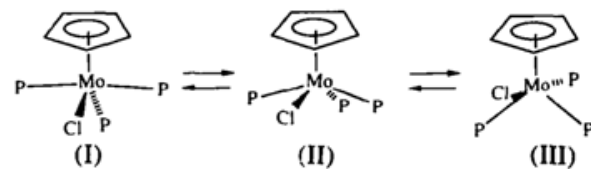

For the $\left[\mathrm{Cp} * \mathrm{MoCl}\left(\mathrm{PMe}_{3}\right)_{3}\right]^{+}$cation of compound (2), the angular distortions are in the opposite direction compared with those of the cation in (3). The Cnt$\mathrm{Mo}-L$ angles are smaller for the $\mathrm{Cl}$ and the $\mathrm{PMe}_{3}$ ligand trans to $\mathrm{Cl}\left[110.0(3)\right.$ and $\left.109.3(3)^{\circ}\right]$, and larger for the other two $\mathrm{PMe}_{3}$ ligands [120.2(3) and $\left.120.5(3)^{\circ}\right]$. In other words, whereas the cation in (1) is the most symmetrical structure [like structure (II) in the scheme above] and the cation in (3) distorts towards structure (I), the cation in (2) distorts in the other direction, towards structure (III). The average $\mathrm{Cnt}-\mathrm{Mo}-L$ angle for the four ligands increases on going from compound (1) $\left(109.7^{\circ}\right)$ and (3) $\left(111.4^{\circ}\right)$ to compound (2) $\left(115^{\circ}\right)$; no doubt an effect of the greater steric bulk of the $\mathrm{Cp}^{*}$ ligand in (2). Compound (2) has $\mathrm{Mo}-\mathrm{P}$ distances similar to those in (3) and an $\mathrm{Mo}-\mathrm{Cl}$ distance intermediate between those of compounds (1) and (3). The Mo-Cnt distance in (2) is significantly longer than those of compounds (1) and (3); perhaps another result of the greater steric interactions in the Cp* complex.

One effect that is identical in both structures examined here [and also in the previously reported structure of (3)] is the shorter Mo- $\mathrm{P}$ bond trans to the $\mathrm{Cl}^{-}$ligand relative to the other two Mo- $\mathrm{P}$ distances (by $c a$ 
$0.050 \mathrm{~A}$ in all cases). This can be rationalized in terms of the weaker trans influence of the $\mathrm{Cl}^{-}$ligand relative to the $\mathrm{PMe}_{3}$ ligand.

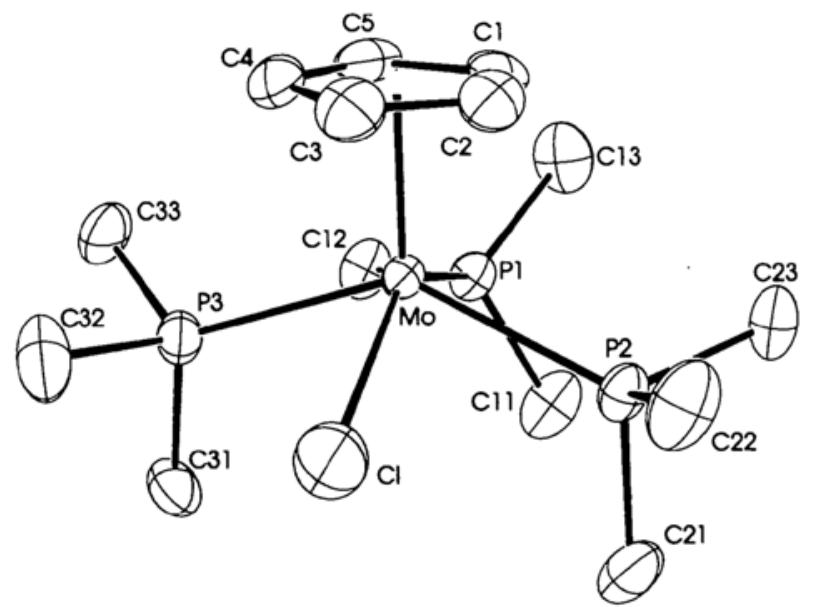

Fig. 1. The molecular configuration and atom-labelling scheme for the $\left[\mathrm{CpMoCl}\left(\mathrm{PMe}_{3}\right)_{3}\right]^{+}$cation. Ellipsoids are drawn at the $40 \%$ probability level.

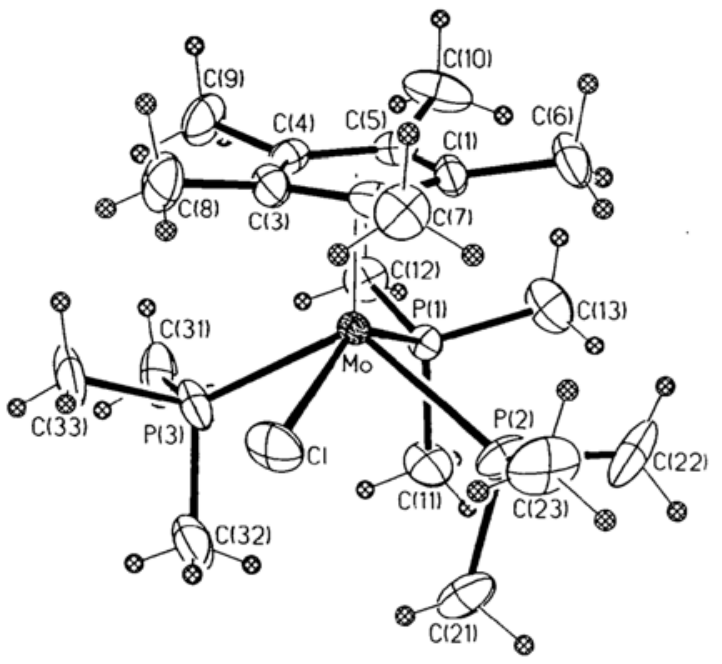

Fig. 2. The molecular configuration and atom-labelling scheme for the $\left[\mathrm{Cp} * \mathrm{MoCl}\left(\mathrm{PMe}_{3}\right)_{3}\right]^{+}$cation. Ellipsoids are drawn at the $40 \%$ probability level.

\section{Experimental}

Compound (1) was obtained by recrystallizing the mixture of products that results from the oxidation of $\left[\mathrm{CpMoH}\left(\mathrm{PMe}_{3}\right)_{3}\right]$ by $\mathrm{AgBF}_{4}$ in tetrahydrofuran from an $n$-heptane-layered $\mathrm{CH}_{2} \mathrm{Cl}_{2}$ solution. Dark red crystals of (2) were obtained by exchanging a $\mathrm{Cl}^{-}$ligand in $\left[\mathrm{Cp} * \mathrm{MoCl}_{2}\left(\mathrm{PMe}_{3}\right)_{2}\right]$ with $\mathrm{PMe}_{3}$, a reaction that is assisted by $\mathrm{TlPF}_{6}$ which precipitates $\mathrm{Cl}^{-}$ as insoluble $\mathrm{TlCl}$, followed by diffusion of $n$-heptane into a $\mathrm{CH}_{2} \mathrm{Cl}_{2}$ solution.
Compound (1)

Crystal data

$\left[\mathrm{MoCl}\left(\mathrm{C}_{5} \mathrm{H}_{5}\right)\left(\mathrm{C}_{3} \mathrm{H}_{9} \mathrm{P}\right)_{3}\right]\left[\mathrm{BF}_{4}\right]$

$M_{r}=511.52$

Monoclinic

$P 2_{1} / c$

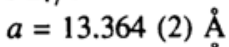

$b=12.991$ (2) $\AA$

$c=13.548(2) \AA$

$\beta=108.350(12)^{\circ}$

$V=2232.4(6) \AA^{3}$

$Z=4$

$D_{x}=1.522 \mathrm{Mg} \mathrm{m}^{-3}$

Data collection

Enraf-Nonius CAD-4 diffractometer

$\theta / 2 \theta$ scans

Absorption correction: empirical ( $\psi$ scans, 4 reflections)

$T_{\min }=0.672, T_{\max }=$ 0.997

3044 measured reflections 2901 independent reflections

\section{Refinement}

Refinement on $F$

$R=0.052$

$w R=0.056$

$S=1.051$

2196 reflections

217 parameters

$w=1 /\left[\sigma^{2}(F)+0.0005 F^{2}\right]$

Compound (2)

Crystal data

$\left[\mathrm{MoCl}\left(\mathrm{C}_{10} \mathrm{H}_{15}\right)\left(\mathrm{C}_{3} \mathrm{H}_{9} \mathrm{P}\right)_{3}\right]-$ $\left[\mathrm{PF}_{6}\right]$

$M_{r}=639.8$

Monoclinic

$P 2 /$ c

$a=12.369$ (6) $\AA$

$b=14.664$ (5) $\AA$

$c=15.769$ (5) $\AA$

$\beta=90.96(3)^{\circ}$

$V=2859.8(20) \AA^{3}$

$Z=4$

$D_{x}=1.486 \mathrm{Mg} \mathrm{m}^{-3}$

\section{Data collection}

Siemens $P 4$ diffractometer $\theta / 2 \theta$ scans

Absorption correction: empirical ( $\psi$ scan) $T_{\min }=0.992, T_{\max }=$ 1.000

4749 measured reflections 4349 independent reflections 3516 observed reflections $[F>4 \sigma(F)]$
Mo $K \alpha$ radiation

$\lambda=0.7107 \AA$

Cell parameters from 25 reflections

$\theta=10.0-16.9^{\circ}$

$\mu=0.93 \mathrm{~mm}^{-1}$

$T=293 \mathrm{~K}$

Block

$0.5 \times 0.5 \times 0.2 \mathrm{~mm}$

Orange-red

2196 observed reflections

$$
[I>1.5 \sigma(I)]
$$

$R_{\text {int }}=0.040$

$\theta_{\max }=22.43^{\circ}$

$h=-14 \rightarrow 13$

$k=0 \rightarrow 13$

$l=0 \rightarrow 14$

3 standard reflections frequency: $60 \mathrm{~min}$ intensity decay: none

$(\Delta / \sigma)_{\max }=0.004$

$\Delta \rho_{\max }=0.76{\mathrm{e} \AA^{-3}}^{-3}$

$\Delta \rho_{\min }=-0.75$ e $\AA^{-3}$

Atomic scattering factors from International Tables for X-ray Crystallography (1974, Vol. IV)

Mo $K \alpha$ radiation

$\lambda=0.7107 \AA$

Cell parameters from 25 reflections

$\theta=20-25^{\circ}$

$\mu=0.821 \mathrm{~mm}^{-1}$

$T=299 \mathrm{~K}$

Block

$0.40 \times 0.32 \times 0.22 \mathrm{~mm}$

Dark red

$R_{\text {int }}=0.012$

$\theta_{\max }=27.50^{\circ}$

$h=-14 \rightarrow 13$

$k=0 \rightarrow 16$

$l=0 \rightarrow 18$

3 standard reflections frequency: $120 \mathrm{~min}$ intensity decay: none 


\section{Refinement}

Refinement on $F$

$R=0.0694$

$w R=0.1193$

$S=1.89$

3516 reflections

281 parameters

$w=1 /\left[\sigma^{2}(F)+0.003 F^{2}\right]$

Table 1. Fractional atomic coordinates and equivalent isotropic displacement parameters $\left(\AA^{2}\right)$ for (1)

\begin{tabular}{lllcc}
\multicolumn{5}{c}{$B_{\text {eq }}=(4 / 3) \sum_{i} \sum_{j} \beta_{i j} \mathbf{a}_{i} \cdot \mathbf{a}_{j}}$. \\
Mo & \multicolumn{1}{c}{$x$} & $y$ & $z$ & $B_{\text {eq }}$ \\
Cl & $0.25760(5)$ & $0.50387(5)$ & $0.24010(5)$ & $2.62(3)$ \\
P1 & $0.41551(23)$ & $0.60739(23)$ & $0.33992(24)$ & $6.86(16)$ \\
P2 & $0.19591(18)$ & $0.32497(17)$ & $0.22955(18)$ & $3.46(11)$ \\
P3 & $0.40076(18)$ & $0.44848(18)$ & $0.16863(18)$ & $3.65(11)$ \\
B & $0.22845(21)$ & $0.53116(19)$ & $0.41194(17)$ & $3.97(11)$ \\
F1 & $0.8129(8)$ & $0.4387(7)$ & $0.2055(8)$ & $3.2(5)$ \\
F2 & $0.8750(6)$ & $0.3650(5)$ & $0.1891(6)$ & $9.0(5)$ \\
F3 & $0.8495(8)$ & $0.5270(6)$ & $0.1815(9)$ & $13.6(9)$ \\
F4 & $0.7156(6)$ & $0.4257(8)$ & $0.1376(7)$ & $11.7(6)$ \\
C1 & $0.8051(9)$ & $0.4393(9)$ & $0.2961(6)$ & $14.2(8)$ \\
C2 & $0.1428(8)$ & $0.5172(7)$ & $0.0798(6)$ & $4.7(5)$ \\
C3 & $0.2114(8)$ & $0.5997(8)$ & $0.0882(7)$ & $4.8(5)$ \\
C4 & $0.2009(9)$ & $0.6644(7)$ & $0.1636(8)$ & $5.3(6)$ \\
C5 & $0.1233(9)$ & $0.6269(8)$ & $0.2023(7)$ & $4.9(5)$ \\
C11 & $0.0867(7)$ & $0.5350(9)$ & $0.1516(8)$ & $4.9(5)$ \\
C12 & $0.2959(8)$ & $0.2267(7)$ & $0.2615(9)$ & $5.8(6)$ \\
C13 & $0.1194(8)$ & $0.2837(7)$ & $0.3129(8)$ & $4.8(5)$ \\
C21 & $0.1080(9)$ & $0.2787(8)$ & $0.1074(8)$ & $6.3(6)$ \\
C22 & $0.5112(8)$ & $0.3819(8)$ & $0.2620(9)$ & $5.8(6)$ \\
C23 & $0.4682(9)$ & $0.5522(9)$ & $0.1249(9)$ & $6.3(6)$ \\
C31 & $0.3694(8)$ & $0.3669(7)$ & $0.0553(7)$ & $5.0(5)$ \\
C32 & $0.3087(9)$ & $0.4504(8)$ & $0.5170(7)$ & $5.2(5)$ \\
C33 & $0.2595(11)$ & $0.6572(9)$ & $0.4669(8)$ & $6.8(7)$ \\
& $0.0968(9)$ & $0.5146(9)$ & $0.4233(8)$ & $6.6(8)$
\end{tabular}

Table 2. Fractional atomic coordinates and equivalent isotropic displacement parameters $\left(\AA^{2}\right)$ for (2)

\begin{tabular}{llrrr} 
& \multicolumn{1}{c}{$x$} & $y$ & $z$ & $U_{\text {eq }}$ \\
Mo & $0.7384(1)$ & $0.1594(1)$ & $0.8207(1)$ & $0.028(1)$ \\
C1 & $0.7094(3)$ & $0.2766(2)$ & $0.7084(2)$ & $0.068(1)$ \\
P1 & $0.7524(2)$ & $-0.0091(2)$ & $0.8386(2)$ & $0.036(1)$ \\
P2 & $0.5514(3)$ & $0.1270(2)$ & $0.7557(2)$ & $0.058(1)$ \\
P3 & $0.9024(3)$ & $0.1439(2)$ & $0.7258(2)$ & $0.057(1)$ \\
P4 & $0.2437(2)$ & $0.3464(2)$ & $0.0145(2)$ & $0.057(1)$ \\
F1 & $0.1767(7)$ & $0.2784(6)$ & $0.0637(6)$ & $0.163(6)$ \\
F2 & $0.3101(8)$ & $0.4157(8)$ & $-0.0336(7)$ & $0.232(10)$ \\
F3 & $0.3471(6)$ & $0.2980(6)$ & $0.0421(6)$ & $0.148(6)$ \\
F4 & $0.2535(9)$ & $0.4065(7)$ & $0.0938(6)$ & $0.176(7)$ \\
F5 & $0.1410(6)$ & $0.3960(7)$ & $-0.0119(8)$ & $0.255(12)$ \\
F6 & $0.2340(10)$ & $0.2864(8)$ & $-0.0627(6)$ & $0.247(12)$ \\
C1 & $0.6646(8)$ & $0.1934(7)$ & $0.9539(6)$ & $0.041(3)$ \\
C2 & $0.6874(9)$ & $0.2748(7)$ & $0.9098(6)$ & $0.045(3)$ \\
C3 & $0.8010(8)$ & $0.2811(7)$ & $0.9015(7)$ & $0.044(3)$ \\
C4 & $0.8463(7)$ & $0.2015(7)$ & $0.9379(6)$ & $0.042(3)$ \\
C5 & $0.7625(9)$ & $0.1496(6)$ & $0.9726(6)$ & $0.041(3)$ \\
C6 & $0.5556(10)$ & $0.1675(8)$ & $0.9910(8)$ & $0.064(4)$ \\
C7 & $0.6070(10)$ & $0.3540(8)$ & $0.8950(9)$ & $0.063(4)$ \\
C8 & $0.8590(11)$ & $0.3644(8)$ & $0.8736(9)$ & $0.070(5)$ \\
C9 & $0.9684(8)$ & $0.1897(9)$ & $0.9537(9)$ & $0.068(5)$ \\
C10 & $0.7803(13)$ & $0.0746(9)$ & $1.0396(7)$ & $0.082(6)$ \\
C11 & $0.7414(11)$ & $-0.0763(8)$ & $0.7408(8)$ & $0.070(5)$ \\
C12 & $0.8769(9)$ & $-0.0556(8)$ & $0.8833(8)$ & $0.057(4)$ \\
C13 & $0.6526(11)$ & $-0.0679(8)$ & $0.9023(9)$ & $0.071(5)$ \\
C21 & $0.5590(11)$ & $0.1009(11)$ & $0.6446(9)$ & $0.080(5)$ \\
C22 & $0.4599(10)$ & $0.0381(10)$ & $0.7910(12)$ & $0.096(7)$ \\
C23 & $0.4600(10)$ & $0.2241(10)$ & $0.7534(9)$ & $0.089(6)$ \\
& & & &
\end{tabular}

$\begin{array}{lllll}\text { C31 } & 1.0165(10) & 0.0616(10) & 0.7443(11) & 0.089(6) \\ \text { C32 } & 0.8692(12) & 0.1203(11) & 0.6174(8) & 0.086(6) \\ \text { C33 } & 0.9836(13) & 0.2474(10) & 0.7160(10) & 0.097(6)\end{array}$

Table 3. Selected geometric parameters $\left(\AA,^{\circ}\right)$ $\mathrm{Cnt}$ is the centroid of the cyclopentadienyl moiety.

$\begin{array}{cc}(1) & (2) \\ 2.509(3) & 2.489(3) \\ 2.455(2) & 2.493(2) \\ 2.506(2) & 2.559(3) \\ 2.504(2) & 2.551(3) \\ 1.971(9) & 2.017(10) \\ 138.5(1) & 140.7(1) \\ 75.36(9) & 74.0(1) \\ 76.9(1) & 75.6(1) \\ 89.4(1) & 85.5(1) \\ 92.3(1) & 85.6(1) \\ 139.5(1) & 118.1(1) \\ 111.9(3) & 110.0(3) \\ 109.7(3) & 109.3(3) \\ 110.1(3) & 120.2(3) \\ 107.2(3) & 120.5(3) \\ & \end{array}$

The title structures (1) and (2) were solved by direct methods using NRCVAX (Gabe, Le Page, Charland, Lee \& White, 1989) and the SHELXTL-Plus program library (Sheldrick, 1987), respectively, to locate the Mo atoms. The remaining non$\mathrm{H}$ atoms were located in the subsequent difference Fourier syntheses. All $\mathrm{H}$ atoms were included in calculated positions $[\mathrm{C}-\mathrm{H}=0.950$ for (1) and $0.960 \AA$ for (2)] with idealized $U[U(\mathrm{H})=1.2(U$ of the attached $\mathrm{C}$ atom $)]$. All non- $\mathrm{H}$ atoms were refined with anisotropic displacement parameters. Due to disorder and/or high thermal motion within the $\mathrm{PF}_{6}$ counterion in compound (2), the anion was restrained to adopt $O_{h}$ symmetry by the use of DFIX instructions (Sheldrick, 1987) with $\mathrm{P}-\mathrm{F}$ distances of $1.52(1) \AA$. Molecular graphics were obtained using ORTEPII (Johnson, 1976).

This work was supported by the DOE Office for Energy Research (92ER14230). Additional support from the NSF (PYI Award 1990-95, CHE-9058375) and the Alfred P. Sloan Foundation (Research Fellowship 199294) is also gratefully acknowledged.

Lists of structure factors, anisotropic displacement parameters, Hatom coordinates and complete geometry have been deposited with the IUCr (Reference: BK1037). Copies may be obtained through The Managing Editor, International Union of Crystallography, 5 Abbey Square, Chester CH1 2HU, England.

\section{References}

Abugideiri, F., Kelland, M. A., Poli, R. \& Rheingold, A. L. (1992). Organometallics, 11, 1303-1311.

Gabe, E. J., Le Page, Y., Charland, J.-P., Lee, F. L. \& White, P. S. (1989). J. Appl. Cryst. 22, 384-387.

Huheey, J. E. (1983). In Inorganic Chemistry, 3rd ed. New York: Harper and Row.

Johnson, C. K. (1976). ORTEPII. Report ORNL-5138. Oak Ridge National Laboratory, Tennessee, USA.

Lin, Z. \& Hall, M. B. (1993). Organometallics, 12, 19-23.

Poli, R. (1990). Organometallics, 9, 1892-1900.

Poli, R. (1992). J. Coord. Chem. 29, 121-173.

Sheldrick, G. M. (1987). SHELXTL-Plus. Version 4.2. Siemens Analytical X-ray Instruments Inc., Madison, Wisconsin, USA. 